\title{
Education M-Health Android-based Smartphone Media Application "Mama ASIX" for Third Trimester Pregnant Women as Preparation for Exclusive Breastfeeding
}

\author{
Mariza Mustika Dewi, Masrifan Djamil, M. Choiroel Anwar \\ Applied Midwifery, Graduate Program, School of Health Polytechnics, \\ Ministry of Health Semarang
}

\begin{abstract}
Background: The lack of exclusive breastfeeding coverage is partly due to the low knowledge of mothers and families regarding the benefits and the right way to breastfeed and not maximally activities education, socialization, advocacy, and campaigns related to exclusive breastfeeding. The purpose of this study was to prove the effectiveness of education $M$-Health using the media application of smartphone Android-based "Mama ASIX" in third trimester pregnant women as preparations for exclusive breastfeeding mothers.

Subjects and Method: This was a quasi experiment study with non-equivalent pretest posttest with control group design. This study was conducted at the Genuk and Pegandan health centers in Semarang, Central Java. The subjects of 36 pregnant women in the third trimester were selected by probability sampling technique were the type of purposive sampling. The independent variables were the application of "Mama ASIX" application and counseling with leaflet, while the dependent variable was the knowledge and attitude of breastfeeding. The instrument in the study is a questionnaire. Data were analyzed using Wilcoxon test and Mann-Whitney test.

Results: Knowledge about breastfeeding increased (mean $=67.78$ to $91.33,95 \% \mathrm{CI}, \mathrm{p}<0.001$ ), breastfeeding attitudes by mothers increased (mean $=68.67$ to $85.9495 \% \mathrm{CI}, \mathrm{p}=0.001$ ), the application "Mama ASIX" is more effective in increasing knowledge of breastfeeding (difference in mean $=23.55,95 \% \mathrm{CI}, \mathrm{p}=0.030$ ) and the attitude of breastfeeding (difference in mean $=17.27$, 95\%CI, $\mathrm{p}=0.029$ ).

Conclusion: Education M-Health using the Android-based smartphone media application "Mama $A S I X "$ in third trimester pregnant women can help mothers prepare exclusive breastfeeding by increasing the knowledge and attitude of breastfeeding for their babies.
\end{abstract}

Keywords: Knowledge, Attitude, Education, MHealth, Android

\section{Correspondence :}

Mariza Mustika Dewi. Applied Midwifery, Graduate Program, School of Health Polytechnics,Ministry of Health Semarang. Jl.Tirto Agung, Pedalangan, Banyumanik, Semarang, Central Java. Email: dewimariza1803@gmail.com. Mobile:+6585865776356.

\section{BACKGROUND}

$\overline{\text { United Nations Children Fund (UNICEF) }}$ and the World Health Organization (WHO) recommend that children should be given the opportunity to initiate early breastfeeding in the first hour of birth, exclusive breastfeeding for six months and continue breastfeeding for two years or more accompanied by complementary foods ASI(Kurniawan, 2013). Indonesia is classified third in the bottom of 51 countries in the world that follows the assessment of the status of policies on feeding programs for infants and children (Infant-Young Child Feeding)(Kurniawan, 2013). Nutritional Status Monitoring results in 2016, the presentation of newborns who received Early Breastfeeding Initiation (IMD) was $51.9 \%$ which consisted of 42.7\% IMD less than one hour after birth and $9.2 \%$ in one hour or more. The Indone- 
sian Health Profile (2017)states that the presentation of infants who have exclusively breastfed until the age of six months is 29.5\%. Central Java Health Profile(2015) states that the percentage of exclusive breastfeeding for infants aged o-6 months over the last three years is $61.6 \%$, in which many districts and cities in the Central Java region that has exclusive breastfeeding percentage are still below standard. Genuk and Pegandan health centers are Puskesmas in the Semarang City Region which is one of the cities in the Central Java region with exclusive breastfeeding coverage under the trend of exclusive breastfeeding coverage in Central Java for 3 consecutive years(Health Service Central Java Region, 2015).

Problems related to exclusive breastfeeding coverage are partly due to the limit6ed number of breastfeeding counselors who provide counseling for mothers which results in low knowledge of mothers and families regarding the correct benefits and ways of breastfeeding and the lack of education, socialization, advocacy, and campaigns related to exclusive breastfeeding (Apriliana et al., 2017). The problems surrounding exclusive breastfeeding in the field were said that the implementation of breastfeeding programs by nutritionists and midwives was not optimal, one of which was due to the lack of attractive program support props (Sari, 2013).

The most widely used tool or media is print media, one of which is a leaflet that has the advantage of being durable, economical and practical, does not require electricity, is easy to carry and easy to understand (Sari, 2013). Research on teaching aids in the form of leaflets showed that there was an increase in knowledge about IMD and exclusive breastfeeding before and after the intervention using leaflets and flipcharts, but in this study it was not known further whether leaflets and flip- charts could change maternal behavior in implementing breastfeeding because leaflets had deficiencies cannot stimulate sound effects, are easily damaged, cannot be upgraded quickly, and require more time and money to print new information (Apriliana et al., 2017).

The studies that have been conducted so far, there is no system or tool that combines education about exclusive breastfeeding, filling out a questionnaire that is giving ASI items to find out how far the knowledge experienced by mothers before and after education, as well as notification of breastfeeding administration as implementation of mothers exclusive breastfeeding for the baby. For this reason, a breakthrough related to health services is necessary, for example by modifying health education programs through information technology (IT) called M-Health (Derbyshire and Dancey, 2013). Mobile Health or M-Health as an attractive method in health intervention is even one of the recommendations from WHO as a breakthrough in health care, especially in the field of counseling and health education that can help overcome health challenges by reducing health costs and time in waiting for treatment(Derbyshire and Dancey, 2013). Health education or-based education mobility seen as a more costeffective approach when compared with conventional methods, such as leaflets. Research conducted by Flax in 2014 stated that smartphones are effective and acceptable in changing women's behavior to promote the practice of exclusive breastfeeding in Nigeria (Flax et al., 2014).

Data on Android users in Indonesia are ranked fifth in the list of users the smartphone largest in the world after China, the United States, Brazil, and Japan with 47.3 million achievements (Flax et al., 2014). Observations made by researchers at the Genuk Health Center got results that 5 of 6 
Journal of Health Promotion and Behavior (2019), 4(2): 98-109

https://doi.org/10.26911/thejhpb.2019.04.02.02

pregnant women used smartphone an Android-based while waiting for their turn to check.

Based on the background, the purpose of this study was to analyze the effectiveness of Education M-Health uses the Android smartphone media application "Mama $A S I X "$ in third trimester pregnant women as preparations for exclusive breastfeeding mothers.

\section{SUBJECTS AND METHOD \\ 1. Study Design}

This studywas an quasi experiment with nonequivalent pretest posttest with control group design approach. Data collection in this study was carried out for 4 weeks consisting of 2 weeks during pregnancy and 2 weeks during childbirth. The study was conducted at Pegandan Health Center and Genuk Health Center in Semarang City in April-June 2018.

\section{Population and Sample}

The population in this study was pregnant women in the third trimester with Estimated Date Delivery (EDD) in April to May 2018. The study sample was 36 pregnant women with purposive sampling type nonprobability sampling technique that satisfies the inclusion and exclusion criteria.

\section{Study Variables}

The dependent variable was the knowledge and attitude of breastfeeding. The independent variable was M-Health Android-based education "Mama ASIX".

\section{Operational of Definition Variables}

M-Health Education based on Android "Mama $A S I X "$ is an application program created by IT programmers with content developed by researchers referring to exclusive breastfeeding counseling of the Central Java Provincial Government which is read 4 times consisting of 2 times in the third trimester and 2 times periods in the puerperium period which included exclusive breas- tfeeding education, questionnaires, breastfeeding tips, notifications, and schedules for breastfeeding.

Leaflet Counseling is the provision of exclusive breastfeeding counseling when pregnant women in the third trimester. Exclusive ASI counseling refers to counseling issued by the Central Java Provincial Government. Knowledge and Attitude of Breastfeeding are the mother's knowledge and attitudes regarding breastfeeding as measured by a questionnaire that has been validity and tested for 2 times, namely pretest during pregnancy and posttest during childbirth with the $0-100$ value range category and has a data ratio.

Education is the level of formal education adopted by pregnant women based on the latest diploma with the categories of elementary, junior high, high school and university. Occupation is an activity carried out by the mother both during pregnancy and after giving birth outside the home with the aim of earning income by working and not working. Parity is the experience of pregnant and giving birth before pregnancy now with the category of primigravida and multigravida.

\section{Data analysis}

Univariate analysis was carried out to see the frequency distribution and characteristics of research respondents. Bivariate analysis includes homogeneity test to determine the variance of confounding variable data in both groups, test for normality of data to determine the distribution of data, Wilcoxon test to determine differences in mean knowledge and attitudes towards independent variables before and after treatment using 95\% confidence level, and Mann-Whitney test to determine the mean difference in the intervention group and post-treatment control using 95\% confidence level (CI). 


\section{Research Ethics}

Research Ethics in this study include informed concent, anonymity, confidentiality, and ethical clearance. Ethical clearance in this study was requested and approved by the Health Research Ethics Committee of the Poltekkes Kemenkes Semarang, Central
Java with number 437 / KEPK / PoltekkesSmg / ec / 2018.

$\frac{\text { RESULT }}{\text { 1. Univariate Analysis }}$

The frequency distribution of study subject characteristics was shown in Table 1.

Table 1. Characteristics of study subjects

\begin{tabular}{lcccc}
\hline \multirow{2}{*}{ Variables } & \multicolumn{2}{c}{ Intervention Group } & \multicolumn{2}{c}{ Control Group } \\
\cline { 2 - 5 } Education & Frequency & Precentage (\%) & Frequency & Precentage (\%) \\
Junior High & 4 & 22.20 & 2 & 11.10 \\
Senior High & 5 & 50 & 13 & 72.20 \\
College & 9 & 27.80 & 3 & 16.70 \\
Occupation & & & & \\
$\quad$ Working & 9 & 50 & 10 & 44.40 \\
$\quad$ Unworking & 9 & 50 & 55.60 \\
Parity & & & & \\
Primigravida & 9 & 50 & 13 & 27.80 \\
Multigravida & 9 & 50 & & 72.20 \\
& & & & \\
\hline
\end{tabular}

Table 1 shows that most mothers have a level senior secondary education. This is shown as the presentation of mothers with senior secondary education by $50 \%$ in the intervention group and $72.20 \%$ in the control group. The presentation of mothers working or not working in the intervention group had the same number whereas in the control group it was found that most moth- ers did not work (55.60). Maternal parity for the intervention group had the same number, whereas in the control group it was seen that most of the mothers were multigravida (72.20).

\section{Bivariate Analysis}

a. Test of Homogeneity

Test of Homogeneity for variable confounding shown in Table 2.

Table 2. Homogeneity test

\begin{tabular}{ccc}
\hline Variables & Levene test & p \\
\hline Education & 1.15 & 0.361 \\
Occupation & 0.66 & 0.626 \\
Parity & 0.66 & 0.622 \\
\hline
\end{tabular}

Results of homogeneity test using Levene test in Table 2 shows that the study $(\mathrm{p}=0.361)$, occupation $(\mathrm{p}=0.626)$, and parity $(p=0.622)$ had the same average between treatment and control groups, meaning that there was no difference in mean education, occupation, and parity between the intervention group and the control gro- up so that it could be concluded that researchers managed to control education, occupation, and parity as confounding variables so as not to give a bias effect on the results of the analysis.

\section{b. Normality Test}

Test of normality data is shown in table 3 . 
Journal of Health Promotion and Behavior (2019), 4(2): 98-109

https://doi.org/10.26911/thejhpb.2019.04.02.02

Table 3. Test of normality data

\begin{tabular}{cc}
\hline Variable & $\mathbf{p}$ \\
\hline Knowledge (pre intervention) & 0.880 \\
Knowledge (post intervention) & 0.004 \\
Attitude (pre intervention) & 0.355 \\
Attitude (post intervention) & 0.003 \\
\hline
\end{tabular}

The results of normality test data using the Shapiro-Wilk test in table 3 shows that knowledge $(\mathrm{p}=0.880)$ and attitude $(\mathrm{p}=$ o.355) before treatment had normal data while knowledge $(\mathrm{p}=0.004)$ and attitude $(\mathrm{p}=$ 0.003) after treatment has abnormal data. Tests for data transformation for abn- ormal data have been carried out and data that has not changed or remains abnormal.

c. Mean of difference breastfeeding on knowledge and attitudes before and after treatment

Mean of difference breastfeeding on knowledge and attitude before and after treatment are described in Table 4.

Table 4.Wilcoxon test

\begin{tabular}{|c|c|c|c|c|c|c|}
\hline \multirow{2}{*}{ Variables } & \multicolumn{3}{|c|}{ Intervention Group } & \multicolumn{3}{|c|}{ Control Group } \\
\hline & Before & After & $\mathbf{p}$ & Before & After & $\mathbf{p}$ \\
\hline \multicolumn{7}{|l|}{ Knowledge } \\
\hline Mean \pm SD & $67.78 \pm 14.55$ & $91.33 \pm 7.48$ & & $70.07 \pm 10.56$ & $85.57 \pm 6.55$ & \\
\hline Min-maks & 41 to 94 & 82 to 100 & 0.000 & 47 to 88 & 76 to 94 & 0.001 \\
\hline \multicolumn{7}{|l|}{ Attitude } \\
\hline Mean \pm SD & $68.67 \pm 18.63$ & $85.94 \pm 12.41$ & 0.001 & $74.11 \pm 12.56$ & $79.56 \pm 9.16$ & 0.075 \\
\hline Min-maks & 42 to 100 & 57 to 100 & & 42 to 100 & 64 to 92 & \\
\hline
\end{tabular}

The results of Wilcoxon test in table 4 show the results in the intervention group mean knowledge $(\mathrm{p}=0.000)$ and attitude $(p=0.001)$ experienced a significant increase. Mean of control group, knowledge and attitudes have increased. The knowledge increased significantly $(\mathrm{p}=0.001)$ while the Table 5. Mann-Whitney Test

\begin{tabular}{lccc}
\hline \multicolumn{1}{c}{ Variables } & Intervention Group & Control Group & p \\
\hline Knowledge & & & \\
Mean Rank & 22.19 & 14.81 & 0.030 \\
Sum of Ranks & 399.50 & 266.50 & \\
Attitude & & & \\
Mean Rank & 22.25 & 14.75 & 0.029 \\
Sum of Ranks & 400.50 & 265.50 & \\
\hline
\end{tabular}

Result of Mann-whitney test in table 5 shows the results of the intervention group had a higher average than the control group. Application "Mama ASIX" is more effe- attitude increased but not significant $(\mathrm{p}=0.075)$.

\section{d. Mean of difference after treatment in intervention and control group}

Mean of difference in the intervention and control groups after treatment is shown in Table 5 . ctive in increasing knowledge $(\mathrm{p}=0.030)$ and the attitude $(\mathrm{p}=0.029)$ of breastfeeding. 


\section{DISCUSSION \\ 1. Sample Characteristics}

The level of education can determine a person's ability to understand and absorb the knowledge gained. People who have a higher education, generally have a broader knowledge and insight so that it is easier to absorb and receive information, and can participate actively in overcoming the health problems of themselves and their families(Health Service Central Java Region, 2015). Characteristics of respondents based on education show that most mothers have a high level of secondary education. This is shown by the presentation of mothers with senior secondary education by $50 \%$ in the intervention group and $72.2 \%$ in the control group. Homogeneity test results on education showed the same average education between the intervention and control groups $(p=0.361)$, meaning that there was no significant difference in mean education between the intervention group and the control group.

The results of statistical tests on education are identical with research conducted in Lampung which states that the level of maternal education does not necessarily affect the level of knowledge and exclusive breastfeeding. This is because one of knowledge is influenced by internal factors such as intelligence, interest, and physical conditions and by external factors such as family and society (Lestari et al,. 2013).

Characteristics of respondents based on occupation showed that the presentation of mothers who worked or did not work in the intervention group amounted to the same while in the control group it was seen that most mothers did not work. The homogeneity test results on the occupation showed the mean of the same work between the intervention and control groups $(\mathrm{p}=$ o.626), meaning that there were no significant differences in mean of work between the intervention group and the control group. Statistical test results showed that there was no difference in the mean of the occupationof the intervention group and the control in this study was in accordance with the research conducted in West Lampung Regency.

Mothers do not work have a greater chance of exclusive breastfeeding than mothers who work. For housewives, unscheduled breastfeeding is not a burden or problem, but for mothers who work outside the home and leave their children for more than 7 hours is a heavy matter. The study in Lampung revealed that mothers who did not work more who did not exclusively breastfeed because work was not the only factor influencing breastfeeding. Mothers who do not work do not necessarily have free time because a lot of household work takes up the minds and energy of the mother so that it affects the production of breastfeeding. The most decisive factor in breastfeeding is knowledge (Lestari et al., 2013).

Characteristics of respondents based on parity showed that maternal parity in the intervention group amounted to the same, whereas in the control group it was seen that most mothers were multigravida. The results of the homogeneity test on parity showed the same parity between the intervention and control groups ( $p=0.622)$, meaning that there was no significant difference in parity between the intervention group and the control group. This is consistent with the total fertility rate (TFR) in the 2012 which stated that an average woman in Indonesia gave birth to 2.6 children during her reproductive period (SDKI, 2012). The results of statistical tests for the parity variables were not in harmony with the research conducted in Karo District, North Sumatra Province which stated that the exper- 
Journal of Health Promotion and Behavior (2019), 4(2): 98-109

https://doi.org/10.26911/thejhpb.2019.04.02.02

iences of mothers had an effect on breastfeeding. This is because mothers who have

\section{Android-based application "Mama} ASIX"

"Mama ASIX" application is an application to facilitate pregnant women in obtaining information about exclusive breastfeeding in preparation for breastfeeding. This appli-
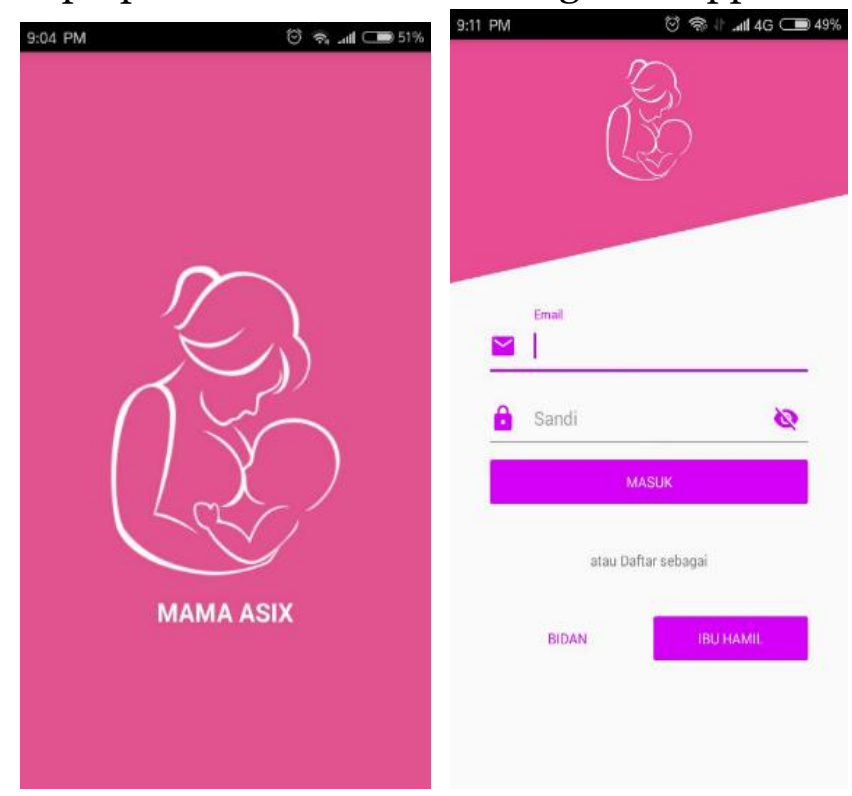

$\square$

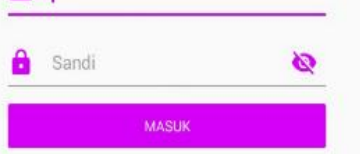

9:17 PM
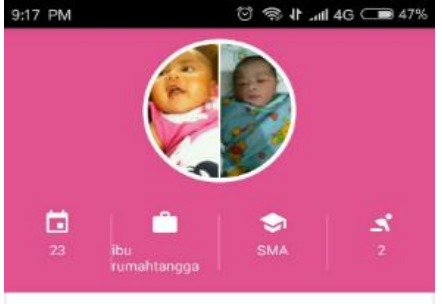

Observasi

Berat Badan Bayi Lahir
3.5

Berat Badan Bayi Sekarang
3.8

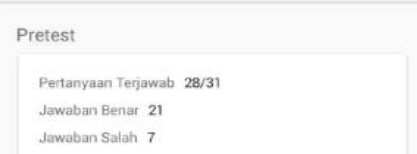

LHAT DETAIL
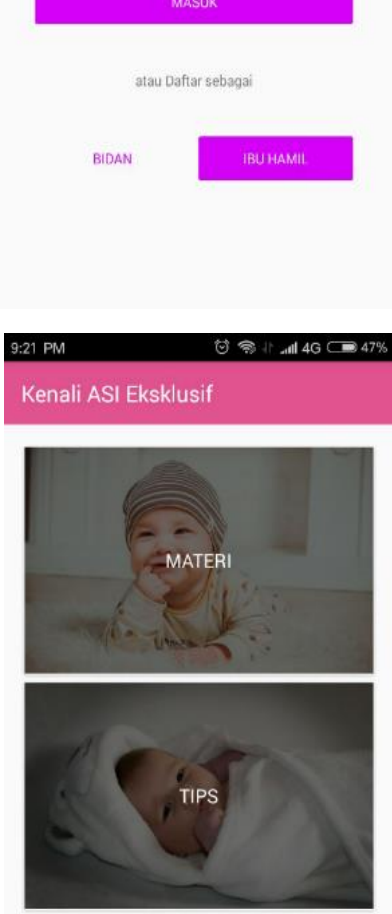

a cation is included in education mobile health because it uses phones mobile as a way to improve health services and save lives. M-Health is one of the important tools in the orientation of client-centered health services that can invite all parties involved to participate(Derbyshire and Dancey, 2013).

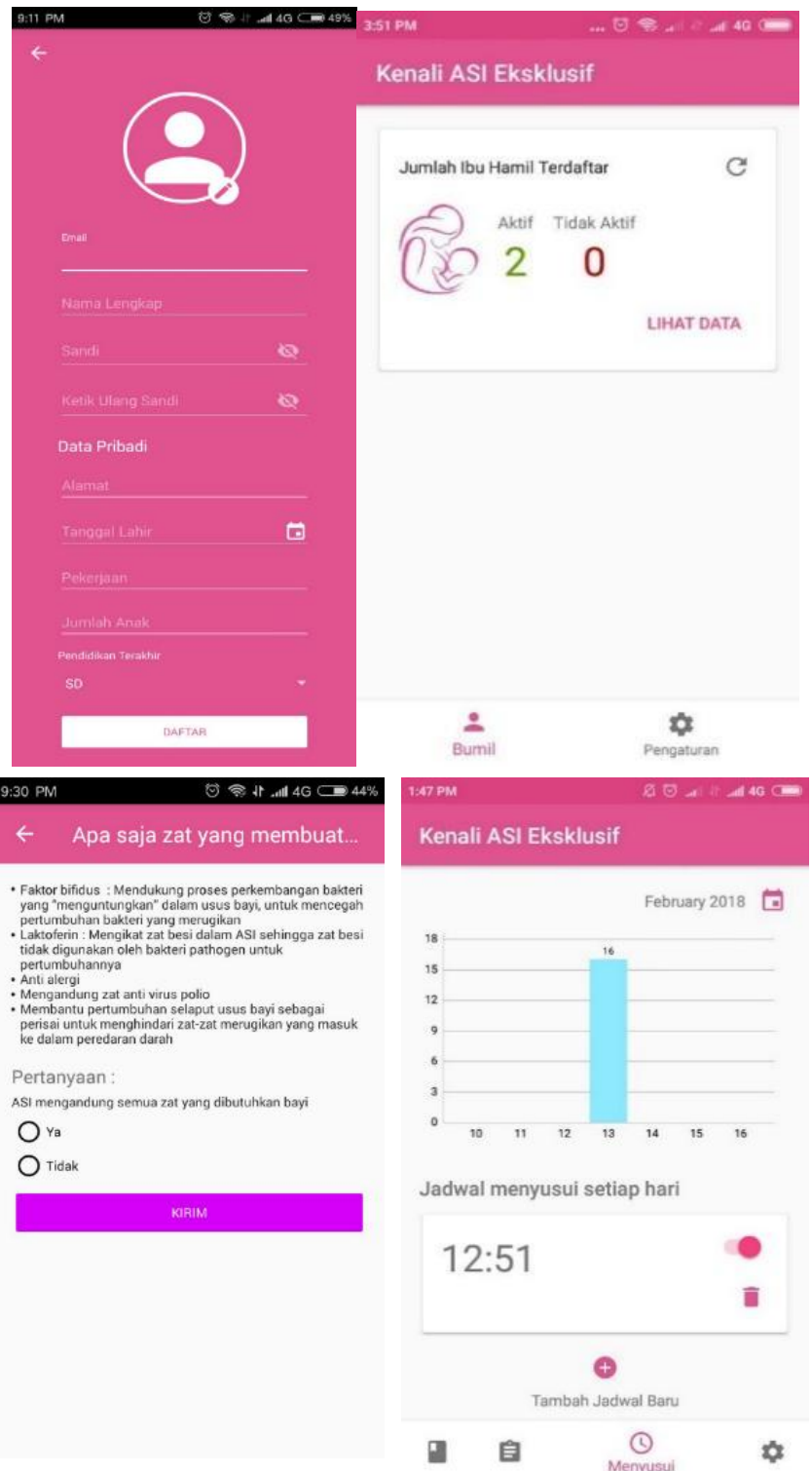

\section{Figure 1. MHealth's Educational Features using Android-Based Applications "Mama ASIX"}

"Mama ASIX" application is expected to help increase the coverage of exclusive breastfeeding which is still low in the city of Semarang due to the lack of education, socialization, advocacy, and campaigns related to exclusive breastfeeding (Apriliana et al., 2017). Previous research states that the implementation of breastfeeding programs 
by nutritionists and midwives has not been optimal. This is because the program supporting props are less attractive (Sari, 2013).

"Mama ASIX" application in this study is an educational props by implementing health mobile or mhealth. This application can be downloaded on smartphones that have an Android operating system. This application can be downloaded via the Play store which is already available on the smartphone. This application is intended for pregnant women to prepare for breastfeeding on their babies after childbirth.

This application can be accessed by midwives and pregnant women. Accounts for pregnant women will be activated by the midwife so that they can be used by pregnant women. This application includes material about exclusive breastfeeding, pretest and post test questions, observation sheets for baby's weight, tips for increasing breast milk, and breastfeeding schedule. "Mama ASIX" application can be seen in Figure 1. Experience have had experience in breastfeeding and baby care (Istiono et al., 2009).

\section{Knowledge and attitude before and after treatment in intervention and control groups}

Test the effect of giving "Mama ASIX" application to the level of knowledge and attitude of giving Breastfeeding using the Wilcoxon test showed that there were significant differences in the level of knowledge $(\mathrm{p}=0.000)$ and breastfeeding attitudes $(\mathrm{p}=0.001)$ before and after treatment in the intervention group. This can be seen from the average knowledge and attitude after treatment is higher than before the treatment.

The development of the use of mobile devices (mobile) such as mobilephones, smartphones, and PDA in recent years have increased rapidly (Chuzaimah and Dihan,
2010). Mobile phones or cellphones are communication devices connected to wireless communication networks through radio waves or satellite transmissions. Mobile phones provide voice communication, SMS (Short Message Service), MMS (Multimedia Message Servicing), and development these devices have been supported by internet services such as browsing and e-mail (Chuzaimah and Dihan, 2010).

Technological advances have made it easier to find information about health promotion, one of which is M-Health or health mobile. WHO defines M-Health as a medical and public health practice supported by devices mobile such as mobile phones, patient monitoring devices, PDAs (personal digital assistance), and other wireless devices (Asiodu et al., 2015). Health Mobile or M-Health is the use of mobile phones as a way to improve health services and save lives. M-Health combines telephone usage with voice messages and short messages (SMS) and smartphones that are equipped with various applications and are intended for the implementation of health programs (Asiodu et al., 2015). This is identical to the research conducted by Budianto (2017) which states that the Android application "Ayah ASI" affects the knowledge and administration of exclusive breastfeeding. Other studies suggest that smartphones are effective and acceptable in changing women behavior to promote exclusive breastfeeding practices in Bauchi City, Nigeria(Flax etal., 2014).

Test the effect of giving leaflets to the level of knowledge and attitude of breastfeeding using the Wilcoxon test there were significant differences in the level of knowledge $(p=0.001)$ before and after treatment in the control group. Test the effect of giving leaflets on breastfeeding attitudes using the Wilcoxon test showed no significant difference in the attitude of breastfeeding 
before and after treatment in the control group ( $\mathrm{p}=0.075)$. Wilcoxon test on attitude shows a significance value of $\mathrm{p}=0.075$, which means that this number is close to $\mathrm{p}=0.05$. It should be assumed that this is because the SD (standard deviation) attitude in the control group is too high, causing the attitude value to be no more homogeneous than the variables of knowledge and weight.

Leaflets are a form of health promotion media or teaching aids in the form of printed media in the form of delivering health information through folded sheets in the form of sentences or pictures or combinations. The advantage of using print media is that the print media is durable, economical and practical, does not require electricity, is easy to carry and easy to understand. While the weakness of the print media is that it canot stimulate sound effects, is easily damaged, cannot be upgraded quickly, and requires more time and money to print new information. The props used for the implementation of health promotion have a large enough role to make targets interested in listening to the material presented(Sari, 2013). This study is in accordance with previous studies which showed that there was an increase in knowledge about IMD and exclusive breastfeeding before and after the intervention using leaflets and flipcharts (Bintu, 2016). The study was strengthened by the results of other studies which stated that there was an effect of counseling using leaflet media on breastfeeding techniques in the context of lactation preparation (Lubis and Triyani, 2016).

\section{M-Health education uses smart- phone media with android-based applications "Mama ASIX" in pregnant women}

Test of the effect to determine differences in the level of knowledge and attitudes of breastfeeding after treatment in both gro- ups using the Mann Whitney test states that the application "Mama ASIX "More effective in increasing knowledge $(\mathrm{p}=0.030)$ and maternal attitudes $(\mathrm{p}=0.029)$ regarding exclusive breastfeeding compared to providing counseling and leaflets. This can be seen from the difference in mean knowledge in the intervention group (23.55) higher than the control group (15.6) and the difference in mean attitudes in the intervention group (17.27) higher than in the control group (5.12).

M-Health can be regarded as an approach and innovation as an effort to reduce maternal mortality worldwide. M-Health refers to the use of mobile and wireless technology to provide health services and information. This can include the use of cellphones, personal digital assistants (PDAs), tablet PCs, applications mobile, and wireless medical devices. M-Health is part of eHealth a larger (electronic health) and includes broader information and communication technology (ICT) for health. M-Health is also part of a crosssector ICT program for community development (Josefa et al., 2018). MHealth can provide information related to health projects that support one of them is a means of education and behavior change(Labrique et al., 2013).

Along with technological developments, the use of Android uses can be used as a health education information media. This is because Android-based smartphone applications are easy to use anywhere because the size of the device is small and easy to carry, has an attractive appearance to facilitate user understanding, and can be done repeatedly. Rapid technological development today, also results in the media used by pregnant women to find out the components of pregnant women 's needs, including preparation of breastfeeding, one of which is the switch from digital information sour- 
ces that previously used conventional paper-based formats (Hmone et al., 2016). Several studies show that the use of-based technology mobile and internet has proven effective in improving knowledge and behavior.

Health education or-based education mobile is seen as a more cost-effective approach when compared with conventional methods, such as counseling, leaflets, brochures. The use of smartphones can improve people's health status and change people's behavior in accordance with health references (Hmone et al., 2016).This is reinforced by research conducted on smartphones and IMD which states that the provision of short messages via smartphones has an effect on Early Breastfeeding Initiation (IMD) (Lionita, 2016).

This research is identical to other research conducted on the application Breastmilk Management that has been carried out in Padang City which explains how the Breast Milk Management Android-based application can regulate and know how to breastfeed infants with working mothers. This Android-based teaching aid has succeeded in helping mothers work in breastfeeding and breastfeeding their babies. This application also adds to the mother's knowledge about breastfeeding milk on her infants (Sonatha et al., 2017).

Another study that supports this study is a study that found that education with MHealth successfully promotes exclusive breastfeeding. This is done with a text message reception system 2-3 times per week for married couples who have babies under four months to give a perception that supplementary feeding for infants less than six months old is not recommended (Hmone et al., 2016). LATCH or Lactation Advice through Texting Can Help is atest mental health controlled by providing two- way text messages that encourage breastfeeding in peer counseling programs at a clinic in America. LACTH counseling is given to pregnant women and evaluated when the pregnant woman has given birth and breastfeeding her baby. This LATCH study has been shown to increase antenatal and postpartum text-based maternal behavioral changes (Josefa et al., 2018).

This study still has many shortcomings, including in terms of methodology and substance. In terms of methodology, this study has not monitored the mother's knowledge and attitudes for 6 months so it is not known whether from the education M-Health Android-based "Mama $A S I X "$ can increase exclusive breastfeeding coverage or not through increased knowledge. When the study, which was only 1 month, was also felt to be less effective in improving attitudes significantly, it was necessary to observe attitudes to obtain changes in maternal behavior in the form of good attitudes towards exclusive breastfeeding.

In terms of the substance of this research, it has not yet assessed the perceptions of program users in depth, so that in the future it is necessary to develop qualitative research related to this program through Focus Group Discussion or In-depth Interview. In this study can be concluded that Education M-Health based on Android "Mama ASIX" is more effective in increasing the knowledge and attitudes of exclusive breastfeeding compared to conventional methods, namely leaflets.

Further researchers are expected to develop this research into quantitativequalitative research in order to increase the effectiveness of research results and are expected to conduct research for up to 6 months to determine the effectiveness of education $M$-Health on exclusive breastfeeding coverage. The Health Service is expect- 
ed to be able to implement and train health workers regarding the Android-based application "Mama ASIX" so that it can be passed on to the community, especially pregnant women to increase knowledge and prepare exclusive breastfeeding to increase Exclusive breastfeeding coverage. The Health Service is also expected to campaign on the application "Mama ASIX" in the community to be widely known and can help mothers to find out information about exclusive breastfeeding.

\begin{tabular}{l}
\hline AUTHOR CONTRIBUTIONS \\
Mariza Mustika Dewi, selected the study \\
subjects, collected the data, measured \\
maternal knowledge and attitude, and \\
wrote the manuscript. Masrifan Djamil \\
gave theoretical suggestion on the use of \\
mobile phone application as a health \\
promotion media. M. Choiroel Anwar did \\
the data analysis and interpreted the results \\
of data analysis.
\end{tabular}

\section{CONFLICT OF INTEREST}

We declare that we do not have any conflict of interest.

\section{FUNDING AND SPONSORSHIP}

There is no external fund and sponsorship.

\section{ACKNOWLEDGEMENT}

We would like to thank Central Java Provincial Health Office for giving permission to collect the data. Thanks to the study subjects in Genuk and Pegandan health centers, Semarang, Central Java, who participated in this study.

\section{REFERENCE}

$\overline{\text { Apriliana K, Runjati (2017).Pengaruh Pend- }}$ idikan Kesehatan dengan Metode Ceramah terhadap Pengetahuan dan Sikap Pemberian ASI Eksklusif pada Ibu Hamil Primigravida di Puskesmas Kapuan tahun 2016. Jurnal Kebidan- an, 6(13): 26-37.

Asiodu IV, Waters CM, Dailey DE, Lee KA, Lyndon A (2015).Breastfeeding and use of social media among first-time African American mothers. Journal of obstetric, gynecologic, and neonatal nursing: JOGNN, 44(2): 268-78. doi: 10.1111/1552-6909.12552.

Bintu EA (2016).Efektivitas Promosi Kesehatan dengan Leaflet dan Flipchart terhadap Perubahan Pengetahuan Ibu Hamil tentang Inisiasi Menyusui Dini (IMD) dan ASI Eksklusif di Wilayah Kerja Puskesmas Anak Air Kota Padang tahun 2016. Jurnal Kesehatan Andalas, 40: 1-5.

Chuzaimah M, Dihan FN (2010). Smartphone: Antara Kebutuhan Dan E-Lifestyle. Smartphone: Antara Kebutuhan dan E-Lifestyle. semnasIF.

Derbyshire E, Dancey D (2013).Smartphone medical applications for women's health: What is the evidence-base and feedback?. International Journal of Telemedicine and Applications. 1-11. doi: 10.1155/2013/782074.

Health Service Central Java Region (2015). Profil Kesehatan Provinsi Jawa Tengah Dinas Kesehatan Provinsi Jawa Tengah. Available at: dinkesjatengprov.go.id/v2015/dokumen/profil 2015/Profil_2015_fix.pdf.

Flax VL, Negerie M, Ibrahim AU, Leatherman S, Daza EJ, Bentley ME (2014). Integrating Group counseling, cell phone messaging, and participantgenerated songs and dramas into a microcredit program increases Nigerian Women's Adherence to International Breastfeeding Recommendations. Journal of Nutrition, 144(7): 11201124. doi: 10.3945/jn.113.190124.

Hmone MP, Dibley MJ, Li M, Alam A (2016). A formative study to inform M-Health based randomized con- 
trolled trial intervention to promote exclusive breastfeeding practices in Myanmar: Incorporating qualitative study findings. BMC Medical Informatics and Decision Making, 16(1): 110. doi: 10.1186/s12911-016-0301-8.

Indonesia Ministry of Health (2017). Health Profile of Indonesia 2016, Profil Kesehatan Provinsi Bali. Jakarta. Retrieved from http://www.depkes.go.id/resources/download/pusdat in/profil-kesehatan-indonesia/ProfilKesehatan-Indonesia-2016.pdf.

Indonesia SDK (2012). Survei Demografi Kesehatan Indonesia 2012.

Istiono W, Suryadi H, Haris M, Irnizarifka, Tahi AD (2009). Analisis FaktorFaktor Yang Mempengaruhi Status Gizi Balita. Jurnal Ilmu Kesehatan Masyarakat, 25(3): 150-155.

Josefa L, Harari N, Segura-Pérez S, Goeschel L, Bozzi V, Pérez-Escamilla R (2018). Impact of the Lactation Advice Through Texting Can Help (LAT$\mathrm{CH}$ ) Trial on Time to First Contact and Exclusive Breastfeeding among WIC Participants. Journal of Nutrition Education and Behavior. Elsevier Inc., 50(1): 33-42.e1. doi: 10.1016/j.jneb.2017.09.001.

Kurniawan B (2013). Determinan keberhasilan pemberian air susu ibu eksklusif. Jurnal Kedokteran Brawijaya, 27(4): 236-240. Retrieved from http://download.portalgaruda.org/article.php? article $=81372 \& v a l=4387$.

Labrique AB, Vasudevan L, Kochi E, Fabricant R, Mehl G (2013). M-Health innovations as health system strengthening tools: 12 common applications and a visual framework. Global Health: Science and Practice, 1(2): 160171. doi: 10.9745/GHSP-D-13-00031.

Lestari D, Zuraida R, Larasati T (2013). Hubungan Tingkat pengetahuan ibu tentang air susu ibu dan pekerjaan ibu dengan pemberian ASI Eksklusif di Kelurahan Fajar Bulan. Medical Jurnal of Lampung University, 2(4): 88-99.

Lionita W (2016). Intervensi pada Perilaku Bidan tentang Pelaksanaan IMD dengan Menggunakan Layanan SMS'.

Lubis R, Triyani S (2016). The Influence Of Giving Counseling In Lactation Preparation By. The Southeast Asian Journal of Midwifery, 7(1): 1-4.

Sari SY (2013). Analisis Implementasi Program Pemberian ASI Eksklusif di Puskesmas Brangsong II Kabupaten Kendal. Jurnal Kesehatan Masyarakat UNDIP. 1: 8143. doi: 10.1017/CBO9781107415324.004.

Sonatha Y, Azmi M, Suryani AI, Sari YP (2017). Pembangunan Aplikasi Breastmilk Management Berbasis Android. Invotek, 17(1): 11-16. 